\title{
World Trade Center Health Program: 20 years after 9/11
}

\author{
Geoffrey M Calvert 두, Dori Reissman, John Howard
}

The September 11, 2001 terrorist attacks in New York City, at the Pentagon in Arlington, Virginia, and at the crash site near Shanksville, Pennsylvania caused over 3000 deaths in the immediate aftermath, and adversely affected the health of hundreds of thousands of respondersthose involved in the rescue, recovery and clean-up efforts following the 9/11 attacks-and survivors-building occupants, residents, workers and students attending schools in the New York City disaster area. The James Zadroga 9/11 Health and Compensation Act of 2010 enacted by Congress and signed into law by President Obama created the World Trade Center (WTC) Health Program to provide healthcare to responders and survivors affected by toxic agent exposures arising from the 9/11 terrorist attacks and their aftereffects. Originally authorised for only 5 years, the WTC Health Program was reauthorised by Congress in 2015 until the year 2090-thereby assuring a lifetime of care for those affected by $9 / 11$ (42 US Code $\mathbb{S S}$ $300 \mathrm{~mm}-300 \mathrm{~mm}-61)$.

Currently, the WTC Health Program has enrolled over 110000 members, and is growing (6\% in the past year). Unlike a traditional health plan which covers a broad scope of medical conditions, the WTC Health Program is a limited benefits health plan. Medical treatment benefits are provided only for those conditions determined to be related scientifically to toxic agent exposures encountered by 9/11 responders and survivors (covered conditions list available at https://www. cdc.gov/wtc/conditions.html). A total of $64015(58 \%)$ members have been awarded medical coverage for at least one WTC-related health condition (also known as 9/11 related). In addition to covering treatment for these WTC-related health conditions, the Program also provides medical and mental health monitoring, cancer screening, diagnostic evaluation, health education and social benefits counselling.

World Trade Center Health Program, NIOSH, Washington DC, District of Columbia, USA

Correspondence to Dr Geoffrey M Calvert, World Trade Center Health Program, NIOSH, 1090 Tusculum Avenue, R-12, Cincinnati, OH 45226, USA; jac6@cdc.gov
Unlike state workers' compensation programmes, where workers often face legal and other obstacles in getting their work-related diseases covered, ${ }^{1}$ obtaining medical coverage for 9/11-related conditions is administratively straightforward. An individual needs to demonstrate that their 9/11 exposure history meets WTC Health Program criteria, provide documentation that they have been diagnosed with a WTC-related health condition that is covered by the Program, obtain an attestation from a Program-affiliated physician that $9 / 11$ exposures were substantially likely to be a significant factor in aggravating, contributing to, or causing the specified health condition, and satisfy requirements that the time interval between the individual's 9/11 exposure and date of disease onset does not deviate from Program minimum or maximum time limits.

Among the Program's successes are its efforts to ensure excellence and efficiency in the delivery of medical monitoring, and evaluation and treatment for both physical and mental health conditions. The Program accomplishes its statutory mission by encouraging the use of high-quality clinical practice guidelines, tracking clinical performance by measuring adherence to various quality assurance metrics, and through collaborative learning from ongoing health surveillance and research. Among other things, such efforts have contributed to: (1) lower than national benchmark rates of unexpected hospital readmissions within 30-day postdischarge (6\% vs $13 \%$, respectively); (2) favourable exceedance of national benchmarks for high quality asthma management among the 18150 members with WTC-related asthma and (3)reducing smoking prevalence to rates $50 \%$ lower compared with the general population $(7 \%$ vs $14 \%$, respectively). ${ }^{2}$

Support of relevant research is another feature of the WTC Health Program. Research activities funded by the Program involve exploring the links between 9/11 exposures and subsequent illness, discovering disease mechanisms and biomarkers of WTC-related conditions, identifying effective healthcare approaches for those conditions, and supporting the 9/11 Health Registry, the world's longest-running and largest postdisaster registry (see https:// www1.nyc.gov/site/911 health/about/wtchealth-registry.page). To date, over 1000 papers have been published related to $9 / 11$, including 11 published in OEM. Two are included in this issue of OEM. ${ }^{34}$ The WTC Health Program's research portfolio has documented the strong linkage between 9/11 exposures and several aerodigestive disorders, many mental health conditions and various cancers. ${ }^{5}$ In this issue, a paper by Webber et al found risks for the following cancers to be elevated among WTC-exposed firefighters after control for potential surveillance bias: thyroid, prostate, malignant melanoma and nonHodgkin's lymphoma. ${ }^{3}$ The other WTCrelated paper published in this issue is helping to increase our understanding of latency between occupational exposure and cancer incidence, which for prostate cancer may be as short as 5.25 years, substantially shorter than studies of non-9/11 occupational exposures. ${ }^{4}$ Cancer research findings among WTC responders and survivors were an important factor leading to the addition in 2012 of most cancer types to the list of covered conditions. ${ }^{6}$ Among the other nine 9/11-related papers previously published in OEM, at least three provided important insights on the early-onset and persistent respiratory effects following 9/11 exposures. ${ }^{7-9}$ The relatively high prevalence of these persistent respiratory complaints were an important driver in initiating the medical screening programmes that existed before the WTC Health Program was formally established in 2011. ${ }^{10}$

In the coming years, the WTC Health Program will face challenges. As 9/11 responders and survivors age, the Program will see its members develop comorbidities that will complicate treatment of their WTCrelated health conditions. To address such complexity, the Program has placed great emphasis on care management and healthcare coordination, making it a lynch pin in the ongoing work at the Program's collaborating Clinical Centres of Excellence (CCE) and the Nationwide Provider Network (NPN). These CCEs are health centres and the NPN is a third party administrator under contract with the Program that use an integrated approach to create a comprehensive suite of health services provided by healthcare professionals with training and experience in various specialties, including occupational and environmental medicine.

The long period of time since the 9/11 terrorist attacks presents another challenge affecting responders and survivors who are currently enrolling or will enrol in the Program in the future. Applicants 
for Program membership need to demonstrate that their 9/11 exposure history meets eligibility criteria. However, the challenges of accurate recall after more than two decades, combined with the bias and barriers related to obtaining employment, school and residential records complicates the validation of 9/11 exposures and subsequent Program entry.

Despite the challenges ahead, the WTC Health Program is a unique federal government health plan that remains steadfast in its mission to provide high-quality healthcare to $9 / 11$ responders and survivors. At the same time, the Program remains dedicated to funding important research about health conditions arising from 9/11 exposures. Finally, the Program serves as a model for the future. A model for how to address the complex health issues that arise in the near and long term from any large-scale environmental disaster.

Twitter Geoffrey M Calvert @gmcalvert1

Contributors GC, DR and JH contributed to the writing of this paper.

Funding The authors have not declared a specific grant for this research from any funding agency in the public, commercial or not-for-profit sectors.

Disclaimer The findings and conclusions in this report are those of the authors and do not necessarily represent the official position of the National Institute for Occupational Safety and Health, Centers for Disease Control and Prevention.

Competing interests None declared.

Patient consent for publication Not required.

Provenance and peer review Commissioned; internally peer reviewed.

(c) Author(s) (or their employer(s)) 2021. No commercial re-use. See rights and permissions. Published by BMJ.

\section{Check for updates}

To cite Calvert GM, Reissman D, Howard J. Occup Environ Med 2021;78:697-698.

Received 15 June 2021

Accepted 29 June 2021

Published Online First 10 September 2021

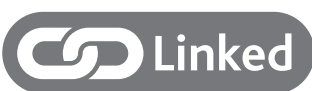

- http://dx.doi.org/10.1136/oemed-2021-107405

- http://dx.doi.org/10.1136/oemed-2021-107570

Occup Environ Med 2021;78:697-698.

doi:10.1136/oemed-2021-107770

\section{ORCID iD}

Geoffrey M Calvert http://orcid.org/0000-0003-39688458

\section{REFERENCES}

1 Utterback DF, Schnorr TM, Silverstein BA, et al. Occupational health and safety surveillance and research using workers' compensation data. J Occup Environ Med 2012;54:171-6.
2 Cornelius ME, Wang TW, Jamal A, et al. Tobacco Product Use Among Adults—United States, 2019. MMWR Morb Mortal Wkly Rep 2020;69:1736-42.

33 Webber MP, Singh A, Zeig-Owens R. Cancer incidence in world trade Center-exposed and non-exposed male firefighters, as compared with the US adult male population: 2001-2016. Occup Environ Med 2021;78:707-14.

4 Goldfarb DG, Zeig-Owens R, Kristjansson D, et al. Temporal association of prostate cancer incidence with world Trade center rescue/recovery work. Occup Environ Med 2021;78:699-706.

5 Santiago-Colón A, Daniels R, Reissman D, et al. World Trade Center Health Program: first decade of research. Int J Environ Res Public Health 2020;17:7290.

6 Daniels RD, Carreón T, Bilics JA, et al. The World Trade Center Health Program: Petitions for adding qualifying health conditions. Am J Ind Med 2021. doi:10.1002/ajim.23267. [Epub ahead of print: 15 Jun 2021].

7 Vossbrinck M, Zeig-Owens R, Hall CB, et al. Post9/11/2001 lung function trajectories by sex and race in World Trade Center-exposed New York City emergency medical service workers. Occup Environ Med 2017;74:200-3.

8 Jordan HT, Friedman SM, Reibman J, et al. Risk factors for persistence of lower respiratory symptoms among community members exposed to the 2001 World Trade Center terrorist attacks. Occup Environ Med 2017;74:449-55.

9 Friedman SM, Farfel MR, Maslow C, et al. Risk factors for and consequences of persistent lower respiratory symptoms among World Trade Center Health Registrants 10 years after the disaster. Occup Environ Med 2016;73:676-84.

10 Reissman DB, Howard J. Responder safety and health: preparing for future disasters. Mt Sinai I Med 2008;75:135-41. 